\title{
GERARD MANLEY HOPKINS
}

Macmillan Literary Lives

General Editor: Richard Dutton, Professor of English,

University of Lancaster

This series offers stimulating accounts of the literary careers of the most widely read British and Irish authors. Volumes follow the outline of writers' working lives, not in the spirit of traditional biography, but aiming to trace the professional, publishing and social contexts which shaped their writing. The role and status of the author' as the creator of literary texts is a vexed issue in current critical theory, where a variety of social, linguistic and psychological approaches have challenged the old concentration on writers as specially gifted individuals. Yet reports of 'the death of the author' in literary studies are (as Mark Twain said of a premature obituary) an exaggeration. This series aims to demonstrate how an understanding of writers' careers can promote, for students and general readers alike, a more informed historical reading of their works. 
Published titles

Morris Beja

JAMES JOYCE

Richard Dutton

WILLIAM SHAKESPEARE

Jan Fergus

JANE AUSTEN

Paul Hammond

JOHN DRYDEN

Joseph McMinn

JONATHAN SWIFT

Kerry McSweeney

GEORGE ELIOT (MARIAN EVANS)

John Mepham

VIRGINIA WOOLF

Michael O'Neill

PERCY BYSSHE SHELLEY

Forthcoming titles

Cedric Brown

JOHN MILTON

Deirdre Coleman

SAMUEL TAYLOR COLERIDGE

Peter Davison

GEORGE ORWELL

James Gibson

THOMAS HARDY

Kenneth Graham

HENRY JAMES

David Kay

BEN JONSON

Mary Lago

E. M. FORSTER
Leonée Ormond

ALFRED TENNYSON

George Parfitt

JOHN DONNE

Gerald Roberts

GERARD MANLEY HOPKINS

Felicity Rosslyn

ALEXANDER POPE

Tony Sharpe

T. S. ELIOT

Cedric Watts

JOSEPH CONRAD

Tom Winnifrith and Edward Chitham

CHARLOTTE AND EMILY BRONTË

John Worthen

D. H. LAWRENCE

Alasdair MacRae

W. B. YEATS

Philip Mallett

RUDYARD KIPLING

Ira Nadel

EZRA POUND

Grahame Smith

CHARLES DICKENS

Gary Waller

EDMUND SPENSER

John Williams

WILLIAM WORDSWORTH

Barry Windeatt

GEOFFREY CHAUCER 


\section{Gerard Manley Hopkins}

A Literary Life

Gerald Roberts 
All rights reserved. No reproduction, copy or transmission of this publication may be made without written permission.

No paragraph of this publication may be reproduced, copied or transmitted save with written permission or in accordance with the provisions of the Copyright, Designs and Patents Act 1988, or under the terms of any licence permitting limited copying issued by the Copyright Licensing Agency, 90 Tottenham Court Road, London W1P 9HE.

Any person who does any unauthorised act in relation to this publication may be liable to criminal prosecution and civil claims for damages.

First published 1994 by

THE MACMILLAN PRESS LTD

Houndmills, Basingstoke, Hampshire RG21 2XS

and London

Companies and representatives

throughout the world

ISBN 978-0-333-56821-7

DOI 10.1007/978-1-349-23350-2

ISBN 978-1-349-23350-2 (eBook)

A catalogue record for this book is available from the British Library 


\section{Contents}

Preface

vii

Acknowledgements

ix

1 The Road to Parnassus 1

2 Choosing the Master $\quad 8$

3 The Convert 20

4 Hopkins and the Jesuits 25

5 The Journal 32

6 The Jesuits 37

7 Towards the 'Deutschland' 44

8 The Return to Poetry 56

9 The Poet and the Priest 73

$\begin{array}{ll}10 \text { Oxford } & 79\end{array}$

11 At Bedford Leigh $\quad 87$

12 Liverpool 93

13 Glasgow 106

14 Training Completed 109

15 At Stonyhurst 115

16 Heraclitean Fire 124 
$\begin{array}{lll}17 & \text { Afterwards } & 143\end{array}$

Further Reading 146

$\begin{array}{ll}\text { Bibliography } & 148\end{array}$

$\begin{array}{ll}\text { Index } & 149\end{array}$ 


\section{Preface}

Sometimes we may pull out a play or a poem ... and see whether it reads differently in the presence of the author. But this again rouses other questions. How far, we must ask ourselves, is a book influenced by its writer's life - how far is it safe to let the man interpret the writer? How far shall we resist or give way to the sympathies and antipathies that the man rouses in us?

One way of approaching Robinson Crusoe ... [is] through the life of the author. Here . . . in the heavenly pastures of biography we may spend more hours than are needed to read the book itself from cover to cover... Only now and then, as we turn from theory to biography and from biography to theory, a doubt insinuates itself - if we knew the very moment of Defoe's birth and whom he loved and why ... should we suck an ounce of additional pleasure from Robinson Crusoe or read it one whit more intelligently?

For the book itself remains.

Virginia Woolf, The Common Reader ${ }^{1}$

The principal aim of this book is to set and evaluate Hopkins's poetry within the context of his own life, particularly that part of it which was spent as a Jesuit, when his major work was written.

As Virginia Woolf's words remind us, it is not always easy to achieve this without implying that biographical knowledge is the indispensable key to critical appreciation. 'Background' information might indeed enable us to understand what was not clear before and, by so doing, increase our ability to enjoy, but the poetry, in Hopkins's case, remains precisely what it was and our critical approach is, or should be, on radically different lines from the biographical.

The few facts provided by his great friend and first editor, Robert Bridges, a rather romantic and brief biography by a fellow Jesuit, ${ }^{2}$ and a scattering of personal reminiscences of unreliable value, meant that, until 1935, Hopkins was a shadowy figure. Since that date, his 
letters, journals, many books and articles, popular and scholarly, have made him one of the most written about, not necessarily best documented, figures of his time. Part of his Jesuit career was minutely covered by Fr Alfred Thomas in a work published in $1969^{3}$ but it was not Fr Thomas's purpose to make a personal assessment of the success of these years or of the poetry written during them.

Later biographical studies have attempted a more literary approach, without neglecting the all-importance of the Jesuit life in so doing. ${ }^{4}$ Even in those periods when no or little poetry was being written - and Hopkins was abnormally sensitive to such times - his spiritual and practical life as a member of that order went on unabated and, no doubt, continued to influence the poetry he was still to write. In Mark Twain's image, a poet is like a reservoir, perpetually accumulating what will eventually result in (to use Wordsworth's phrase) the 'spontaneous overflow of powerful feelings'.

Writing in her Four Metaphysical Poets more than fifty years ago, Joan Bennett declared that a 'background of common experience' as a human being is the principal requirement in reading Hopkins, adding, however: 'Given two readers of equal sensibility the more widely read has always an advantage. ${ }^{\prime 5}$ Although I recognise the truth of this qualification, I would not seek to exaggerate it: the reader of Hopkins who knows 'everything' about the poet is in danger of not seeing the wood for the trees. In the end, as Virginia Woolf puts it, the poetry 'itself remains', and the appreciation and enjoyment of it is the ultimate purpose to which this study is directed.

\section{Notes}

1. V. Woolf, The Common Reader, Second Series (London, 1965) pp. 263 and 51-2.

2. Fr G. F. Lahey, Gerard Manley Hopkins (London, 1930)

3. Fr A. Thomas, Hopkins the Jesuit: The Years of Training (London, 1969).

4. The most recent of these biographies, Norman White's Hopkins: A Literary Biography (London, 1992), came too late to make use of in this book.

5. Reprinted in Hopkins: The Critical Heritage, ed. G. Roberts (London, 1987) pp. 289-90. 


\section{Acknowledgements}

The author is grateful to Professor Dutton, General Editor of the series, for his help and encouragement in writing this book. He would also like to thank Fr Edwards and Fr Holt of the Society of Jesus for granting access to the Archives of the English Society at Farm Street, London. Fr Turner SJ, Archivist of Stonyhurst College, has kindly answered a number of queries. The author has made frequent use of the facilities of the University Libraries of Lancaster, Sussex, and Royal Holloway, as well as the British Library, where the staffs have been uniformly helpful.

G.R. 